\title{
Implementasi Augmented Reality dengan Memanfaatkan GPS Based Tracking pada Sistem Pengenalan Gedung Universitas Tanjungpura
}

\author{
Steven Pragestu ${ }^{1,}$ Herry Sujiani ${ }^{2,}$ Arif Bijaksana Putra Negara ${ }^{3}$ \\ ${ }^{123}$ Program Studi Teknik Informatika Fakultas Teknik Universitas Tanjungpura \\ e-mail: stevenpragestu@gmail.com, herry_sujaini@yahoo.com, arifbpn@gmail.com
}

\begin{abstract}
Abstrak-Universitas Tanjungpura (UNTAN) merupakan universitas negeri yang berada di kota Pontianak. UNTAN memiliki banyak gedung yang tersebar pada lahan dengan luas areal $12.135 \mathrm{~m}^{2}$. Banyaknya gedung ini membuat sebagian orang akan kesulitan dalam mengenali dan mendapatkan informasi mengenai gedung yang berada dalam lingkungan UNTAN. Interaktivitas menjadi salah satu poin yang penting dalam pengembangan sebuah aplikasi. Teknologi Augmented Reality (AR) adalah salah satu teknologi interaksi yang dapat mengintegrasikan obyek virtual dengan lingkungan nyata secara real-time. AR memungkinkan user untuk berinteraksi dengan obyek virtual secara natural. AR yang diimplementasikan pada aplikasi bekerja dengan cara memberikan label pada gedung yang ditampilkan oleh layar smartphone. Teknik tracking AR yang digunakan pada penelitian ini adalah GPS based tracking, dimana teknik ini memanfaatkan data koordinat yang dimiliki oleh gedung untuk memberikan label pada gedung. Pengujian pada penelitian ini dilakukan dengan pengujian akurasi dan kuesioner. Berdasarkan hasil dari pengujian akurasi yang dilakukan, aplikasi yang diimplementasikan dengan teknologi AR ini dapat mengenali gedung dari depan, sisi belakang, sisi kiri maupun sisi kanan gedung dan dari jarak dekat, sedang maupun jauh. Berdasarkan kuesioner yang dibagikan kepada 100 responden, didapatkan bahwa aplikasi yang diimplementasikan dengan teknologi AR dapat mempermudah masyarakat kota Pontianak untuk mengenali gedung yang berada di lingkungan UNTAN, sebesar $89 \%$ responden yang merasa dimudahkan oleh teknologi AR. Masyarakat kota Pontianak lebih dimudahkan dengan fitur teknologi AR untuk mengenali gedung di UNTAN daripada menggunakan fitur peta digital, dimana persentase pemilih teknologi AR sebesar $96 \%$.
\end{abstract}

Kata Kunci-Android, sistem pengenalan gedung, universitas tanjungpura, augmented reality, GPS based tracking.

\section{PENDAHULUAN}

$\mathrm{U}$ Jniversitas Tanjungpura (UNTAN) merupakan universitas negeri yang berada di Kota Pontianak. UNTAN memiliki banyak gedung yang tersebar pada lahan dengan luas areal $12.135 \mathrm{~m}^{2}[1]$. Banyaknya gedung ini membuat sebagian orang akan kesulitan dalam mengenali gedung yang berada dalam lingkungan UNTAN.

Peranan teknologi dapat menjadi pilihanyang tepat dalam memberikan informasi yang cepat dan akurat.Saat ini smartphone didukung dengan teknologi yang canggih danmobilitas yang tinggi. Berdasarkan hal tersebut,maka smartphone dapat menjadi pilihan yang paling tepat sebagai alternatif lain media pemberi informasi kebutuhan user.

Seiring dengan perkembangan teknologi, interaktivitas menjadi salah satu poin yang penting dalam pengembangan sebuah aplikasi.Salah satu teknologi interaksi yang sedang berkembang saat ini adalah teknologi Augmented Reality.Augmented Reality (AR) merupakan teknologi yang dapat mengintegrasikan obyek virtualdengan lingkungan nyata secara real-time[2], sehingga teknologi AR memungkinkan user untuk berinteraksi dengan dengan obyek virtual secara natural. Aplikasi yang dibuat nantinya akan memanfaatkan sensor-sensor yang terdapat pada smartphone Android untuk mengenali letak gedung dan teknologi AR untuk memberi label pada gedung yang ditampilkan oleh layar smartphone.

Penelitian serupa pernah dilakukan oleh Diaz Hendrianto dkk[3], dimana dalam penelitian yang dilakukannya mereka memanfaatkan sensor akselerometer, kompas, dan GPS untuk menentukan posisi masjid dari posisi userdan untuk menampilkan hasilnya mereka menggunakan teknologi AR,dimana hasil penelitiannya adalah Point of Interest (POI) masjid dapat ditampilkan pada layar smartphone dengan menghitung nilai dari sensor akselerometer, kompas dan GPS.

Berdasarkanmasalah yang ada yaitu sulitnya mengenali gedung yang terdapat pada lingkungan Universitas Tanjungpura dan dengan melihat fungsi teknologiAR yang dapat memvisualisasikan informasi secara interaktif dan nyata, maka diimplentasikanlah teknologi AR pada sistem pengenalan kampus UNTAN berbasis Android.

\section{URAIAN PENELITIAN}

\section{A. Augmented Reality}

Realitas tertambah, atau kadang dikenal dengan singkatan bahasa Inggrisnya Augmented Reality(AR), adalah teknologi yang menggabungkan benda maya dua dimensi dan ataupun tiga dimensi ke dalam sebuah lingkungan nyata tiga dimensi lalu memproyeksikan benda-benda maya tersebut secara realtime[4]. 


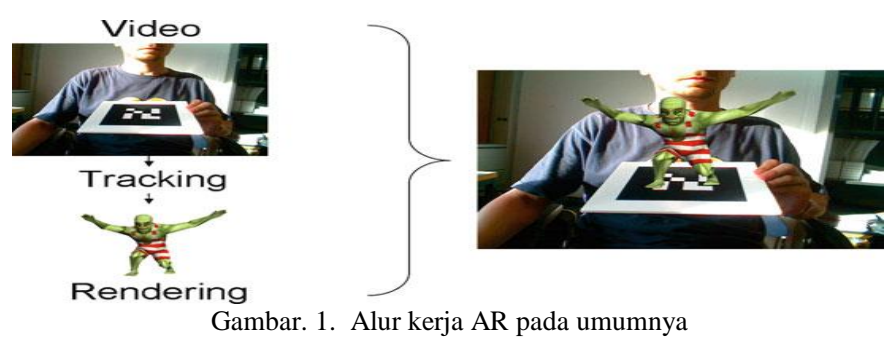

Cara kerja AR dalam menambahkan obyek virtual ke lingkungan nyata adalah sebagai berikut[5].

1. Citra dunia nyata diambil dari kamera.

2. Dimulai proses tracking untuk mendapatkan posisi rendering obyek virtual.

3. Obyek virtual dimasukkan ke citra nyata berdasarkan hasil tracking sebelumnya.

\section{B. GPS Based Tracking}

Teknik GPS based tracking saat ini mulai populer dan banyak dikembangkan pada aplikasi smartphone. Teknik ini memanfaatkan fitur GPS dan kompas yang ada didalam smartphone. Aplikasi akan mengambil data dari GPS dan kompas kemudian menampilkan obyek virtual sesuai dengan arah yang kita inginkan secara real-time, bahkan ada beberapa aplikasi menampikan obyek virtual dalam bentuk 3D [6].

\section{Android}

Android adalah sistem operasi bergerak (mobile operating system) yang mengadopsi sistem operasi Linux, namun telah dimodifikasi.Android diambil alih oleh Google pada tahun 2005 dari Android, Inc sebagai bagian strategi untuk mengisi pasar mobile operating system.Google mengambil alih seluruh hasil kerja Android termasuk tim yang mengembangkan Android. Google menginginkan agar Android bersifat terbuka dan gratis, oleh karena itu hampir setiap kode program Android diluncurkan berdasarkan lisensi opensourceApache[7].

\section{AndroidAR-Framework}

Penelitian ini menggunakan AR framework yang bernama android-augment-reality-frameworkuntuk mengimplementasikan teknologi AR terhadap aplikasi yang dibuat.AR framework ini dibuat oleh Justin Wetherell.Berikut adalah spesifikasi maupun fitur dari AR framework ini[8].

1. API level minimum : 4 .

2. User dapat mengatur radius dari koleksi data dari $0 \mathrm{~m}$ hingga $100.000 \mathrm{~m}(100 \mathrm{~km})$.

3. Tampilan POI akan berubah sesuai dengan gerakan user.

4. Radar kecil untuk menampilkan POI yang tersedia diluar dari pandangan.

5. Post dari twitter dan artikel dari wikipedia yang terletak disekitar user dapat ditampilkan [9].

\section{E. Perancangan Sistem}

Sistem yang dirancang berbasis client-server, Usermengakses sistem untuk mengenali gedung di lingkungan
Universitas Tanjungpura dengan menggunakan smartphone Android dan web browser. Admin mengakses sistem melalui web browser untuk memanajemen gedung.Berikut pada Gambar 2 menunjukkan arsitektur sistem yang dibangun.

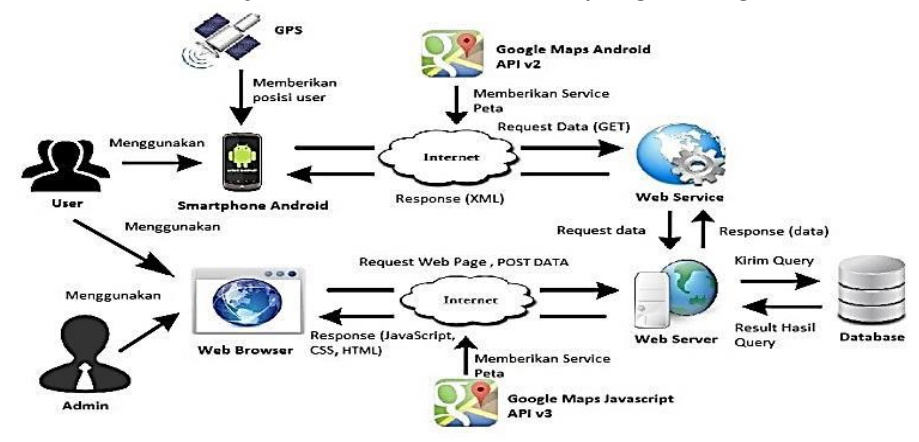

Gambar2. Arsitektur sistem

\section{F. Use Case Diagram}

Use casediagramatau diagram use case merupakan pemodelan untuk kelakukan (behavior) sistem informasi yang akan dibuat. Use case mendeskripsikan sebuah interaksi antara satu atau lebih aktor dengan sistem informasi yang akan dibuat [10].Berikut merupakan use case diagram sistem yang dapat dilihat pada Gambar 3.

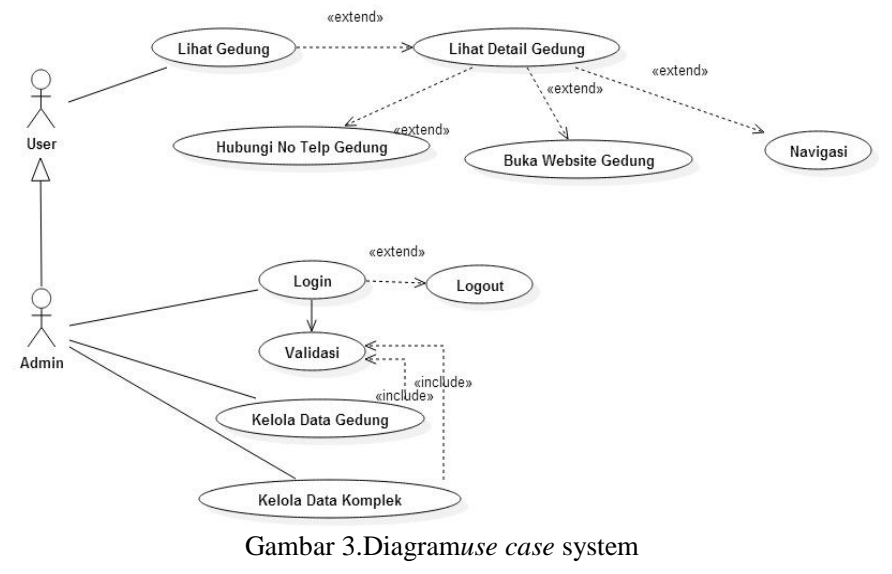

Admin dapat melakukan login untuk mendapatkan hak akses dan dapatmelakukan proses kelola data gedung dan komplek.Userdapat melihat gedung melalui media peta digital maupun augmented reality, melihat detail gedung, menghubungi nomor telepon gedung, membuka website gedung dan navigasi ke gedung.

\section{G. Pengujian Kompatibilitas}

Pengujian kompatibilitas dilakukan untuk menguji kinerja operasi aplikasi di berbagai jenis perangkat Android yang memenuhi syarat perangkat lunak.Aspek-aspek yang ditinjau dalam pengujian ini adalah versi OS dan hasil eksekusi/operasional aplikasi.

\section{H. Pengujian Akurasi}

Pengujian ini dilakukan dengan cara mencobakan aplikasi terhadap 3 gedung yang berada di lingkungan UNTAN dari berbagai sisi gedung, yaitu sisi depan, kiri, kanan maupun belakang gedung dan dengan jarak yang berbeda, yaitu jarak dekat $(0-5 \mathrm{~m})$, sedang $(5-30 \mathrm{~m})$ maupun jauh $(>30 \mathrm{~m})$. Tujuan 
dari pengujian ini adalah untuk mengukur akurasi POI terhadap gedung yang berada di UNTAN.

\section{Hasil Kuesioner}

Kuesioner dibagikan terhadap 100 responden yang merupakan masyarakat kota Pontianak. Pertanyaan pada kuesioner mencangkup 3 aspek yaitu aspek rekayasa perangkat lunak, aspek fungsionalitas dan aspek komunikasi visual, dan 1 pertanyaan tambahan untuk mengetahui respon pengguna terhadap teknologi yang lebih mudah untuk mengenali gedung di lingkungan Universtitas Tanjungpura.

Penyajian hasil kuesioner dibagi menjadi beberapa bagian yaitu distribusi pemilih AR dan MAP untuk mengetahui fitur apa yang lebih memudahkan user untuk mengenali gedung di UNTAN, hasil dari aspek rekayasa perangkat lunak, fungsionalitas dan komunikasi visual untuk mengetahui penilaian responden terhadap aplikasi yang dibuat sesuai dengan aspeknya, pengelompokan tanggapan Augmented Reality untuk mengetahui tanggapan userterhadap teknologi AR yang diimplementasikan pada aplikasi dan User Acceptance Test (UAT) untuk mengetahui tingkat keberhasilan aplikasi yang dibuat.

\section{HASIL DAN DISKUSI}

\section{A. Hasil Perancangan}

Aplikasi yang dibangun berfungsi sebagai media informasi yang dapat digunakan pengguna untuk mengenali gedung yang berada di lingkungan Universitas Tanjungpura. Aplikasi yang dibuat terdiri dari 2 jenis aplikasi yaitu web app dan Android app.

Web app digunakan oleh user untuk mengenali gedung yang berada di Universitas Tanjungpura dan digunakan admin untuk mengelola data-data gedung.Web app dapat diakses melalui webbrowser. Basis media yang digunakan pada web app adalah peta digital.
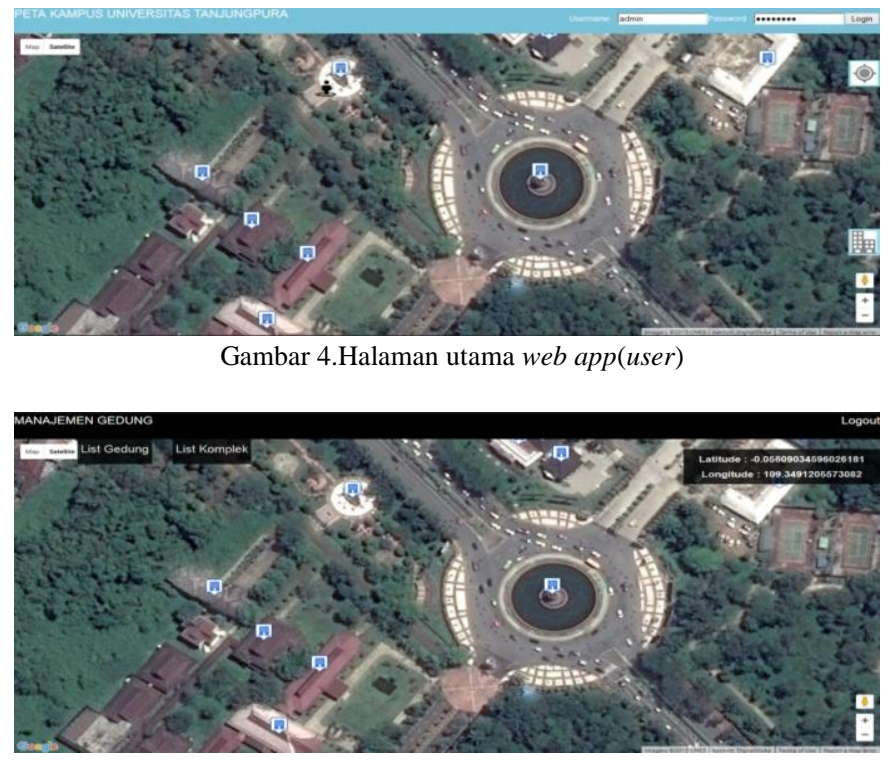

Gambar 5.Halaman utama web app(admin)
Android Appadalah aplikasi berbasis Android yang dapat digunakan user untuk mengenali gedung yang berada di Universitas Tanjungpura. Basis media yang digunakan pada Android app adalah peta digital dan Augmented Reality.

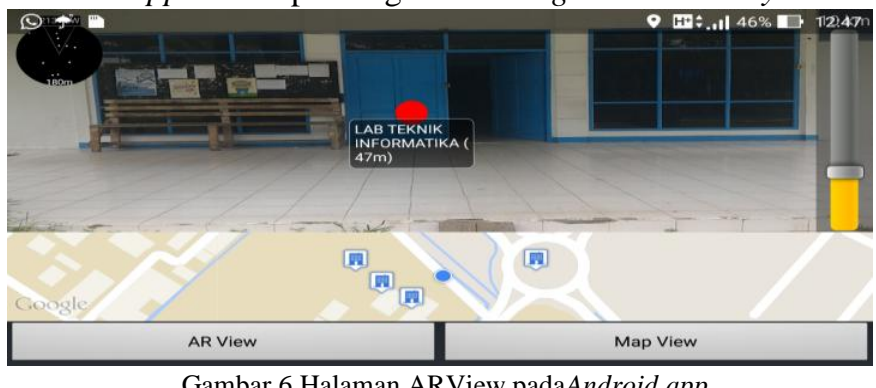

Gambar 6.Halaman ARView padaAndroid app

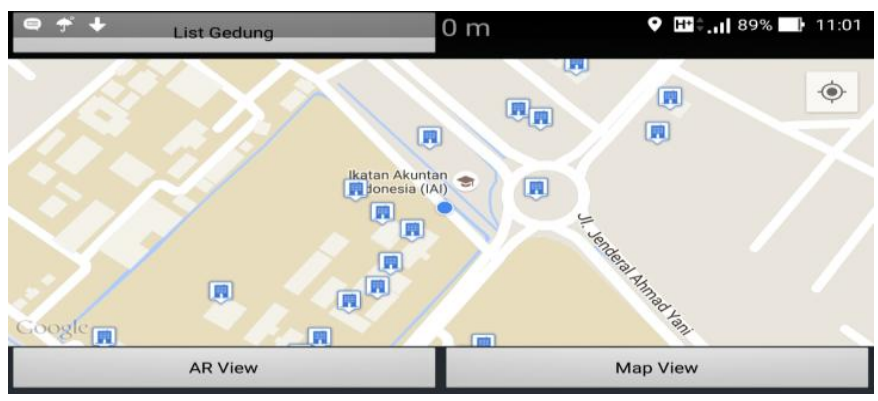

Gambar 7.Halaman Map View pada Androidapp

\section{B. Hasil Pengujian Kompatibilitas}

Pengujian kompatibilitas merupakan pengujian keseluruhan operasional aplikasi pada berbagai jenis perangkatAndroid.Pada pengujian kompatibilitas ini, aplikasi diuji mulai dari tahap instalasi hingga saat dioperasikan pada perangkat.Pada penelitian ini, digunakan 8 perangkat Android dengan versi Android 2.3 (Gingerbread) hingga Android 5.1 (Lollipop).Tabel 1berikut menunjukkan hasil pengujian kompatibilitas.

Tabel1.

Hasil pengujian kompatibilitas

\begin{tabular}{|c|l|c|c|}
\hline No & \multicolumn{1}{|c|}{$\begin{array}{c}\text { Nama } \\
\text { Perangkat }\end{array}$} & $\begin{array}{c}\text { Versi } \\
\text { Android }\end{array}$ & Keterangan \\
\hline 1. & Samsung Galaxy Ace 2 & 2.3 & GAGAL \\
\hline 2. & Samsung Galaxy W & 4.0 & OK \\
\hline 3. & Samsung Galaxy Tab 3.7.0 & 4.1 & OK \\
\hline 4. & Evercoss A7X & 4.2 & OK \\
\hline 5. & Samsung Galaxy S3 & 4.3 & OK \\
\hline 6. & Samsung Galaxy Grand 2 & 4.4 & OK \\
\hline 7. & ASUS Zenfone 2 ZE550ML & 5.0 & OK \\
\hline 8. & ASUS Zenfone 2 ZE551ML & 5.1 & OK \\
\hline
\end{tabular}

\section{Hasil Pengujian Akurasi}

Pengujian akurasi dilakukan terhadap 3 gedung di UNTAN yaitu Lab. Teknik Informatika UNTAN, Sekretariat Fakultas Pertanian UNTAN dan Rektorat UNTAN dari sisi depan, belakang, kiri maupun kanan gedung dan jarak dekat $(0-5 \mathrm{~m})$, sedang (5-30 m), dan jauh (>30m). 
Berikut adalah hasil dari pengujian akurasi Android Appdalam mengenali gedung di lingkungan UNTAN yang dapat dilihat pada Tabel 2.

Tabel2.

Hasil pengujian akurasi

\begin{tabular}{|c|c|c|c|c|c|}
\hline No & $\begin{array}{c}\text { Nama } \\
\text { Gedung } \\
\text { Referensi }\end{array}$ & $\begin{array}{c}\text { Sisi } \\
\text { Referensi } \\
\text { Pengujian }\end{array}$ & $\begin{array}{c}\text { Jarak } \\
\text { Referensi } \\
\text { Pengujian }\end{array}$ & $\begin{array}{c}\text { Hasil } \\
\text { Pengujian }\end{array}$ & $\begin{array}{c}\text { Kesim- } \\
\text { pulan }\end{array}$ \\
\hline 1. & \multirow{9}{*}{$\begin{array}{l}\text { LAB } \\
\text { TEKNIK } \\
\text { INFORMA } \\
\text { TIKA } \\
\text { UNTAN }\end{array}$} & Kiri & Dekat & \multirow{9}{*}{$\begin{array}{l}\text { LAB } \\
\text { TEKNIK } \\
\text { INFORMA } \\
\text { TIKA } \\
\text { UNTAN }\end{array}$} & Sesuai \\
\hline 2. & & Kiri & Sedang & & Sesuai \\
\hline 3. & & Kiri & Jauh & & Sesuai \\
\hline 4. & & Kanan & Dekat & & Sesuai \\
\hline 5. & & Kanan & Sedang & & Sesuai \\
\hline 6. & & Kanan & Jauh & & Sesuai \\
\hline 7. & & Depan & Dekat & & Sesuai \\
\hline 8. & & Depan & Sedang & & Sesuai \\
\hline 9. & & Depan & Jauh & & Sesuai \\
\hline 10. & \multirow{9}{*}{$\begin{array}{l}\text { SEKRETA } \\
\text { RIAT } \\
\text { FAKULTA } \\
\text { S } \\
\text { PERTANI } \\
\text { AN } \\
\text { UNTAN }\end{array}$} & Kiri & Dekat & \multirow{9}{*}{$\begin{array}{l}\text { SEKRETA } \\
\text { RIAT } \\
\text { FAKULTA } \\
\text { S } \\
\text { PERTANI } \\
\text { AN } \\
\text { UNTAN }\end{array}$} & Sesuai \\
\hline 11. & & Kiri & Sedang & & Sesuai \\
\hline 12. & & Kiri & Jauh & & Sesuai \\
\hline 13. & & Kanan & Dekat & & Sesuai \\
\hline 14. & & Kanan & Sedang & & Sesuai \\
\hline 15. & & Kanan & Jauh & & Sesuai \\
\hline 16. & & Belakang & Dekat & & Sesuai \\
\hline 17. & & Belakang & Sedang & & Sesuai \\
\hline 18. & & Belakang & Jauh & & Sesuai \\
\hline 19. & \multirow{9}{*}{$\begin{array}{l}\text { REKTOR } \\
\text { AT } \\
\text { UNTAN }\end{array}$} & Kiri & Dekat & \multirow{9}{*}{$\begin{array}{l}\text { REKTOR } \\
\text { AT } \\
\text { UNTAN }\end{array}$} & Sesuai \\
\hline 20. & & Kiri & Sedang & & Sesuai \\
\hline 21. & & Kiri & Jauh & & Sesuai \\
\hline 22. & & Kanan & Dekat & & Sesuai \\
\hline 23. & & Kanan & Sedang & & Sesuai \\
\hline 24. & & Kanan & Jauh & & Sesuai \\
\hline 25. & & Depan & Dekat & & Sesuai \\
\hline 26. & & Depan & Sedang & & Sesuai \\
\hline 27. & & Depan & Jauh & & Sesuai \\
\hline
\end{tabular}

Berdasarkan hasil pengujian yang dilakukan, didapatkan percobaan yang berhasilsebanyak 27 percobaan dari 27 percobaan, dimana pada semua percobaan POI yang dihasilkan oleh aplikasi sesuai dengan gedung yang diujikan, sehingga didapatkan nilai akurasi sebesar $100 \%$.

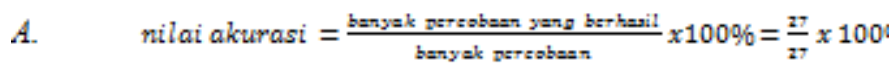

\section{Hasil Kuesioner}

Tabel3.

Hasil kuesioner pemilih AR dan MAP

\begin{tabular}{|c|c|c|}
\hline Tanggapan & Banyak pemilih & Persentase \\
\hline AR & 96 & 96 \\
\hline MAP & 4 & 4 \\
\hline
\end{tabular}

Tabel 3 berikut merupakan hasil dari pembagian kuesioner kepada 100 responden mengenai fitur yang lebih memudahkan dalam mengenali gedung di UNTAN.
Tabel4.

Hasil kuesioner

\begin{tabular}{|c|c|c|c|c|c|c|}
\hline & \multirow{3}{*}{$\begin{array}{l}\text { Aspek Rekayasa } \\
\text { Perangkat Lunak }\end{array}$} & & & & & \\
\hline \multirow{2}{*}{ No } & & \multicolumn{5}{|c|}{ Tanggapan } \\
\hline & & 1 & 2 & 3 & 4 & 5 \\
\hline \multicolumn{7}{|c|}{ Aspek Rekayasa Perangkat Lunak } \\
\hline 1 & $\begin{array}{l}\text { Kemudahan } \\
\text { menjalankan aplikasi }\end{array}$ & 0 & 0 & 6 & 59 & 35 \\
\hline 2 & $\begin{array}{l}\text { Kelancaran } \\
\text { menjalankan aplikasi }\end{array}$ & 0 & 0 & 7 & 62 & 31 \\
\hline 3 & $\begin{array}{l}\text { Kemudahan akses fitur } \\
\text { aplikasi }\end{array}$ & 0 & 0 & 9 & 60 & 31 \\
\hline 4 & Ketepatan POI gedung & 0 & 0 & 16 & 53 & 31 \\
\hline 5 & $\begin{array}{l}\text { Kelengkapan fitur } \\
\text { aplikasi }\end{array}$ & 0 & 0 & 21 & 73 & 6 \\
\hline \multicolumn{2}{|c|}{ Total } & 0 & 0 & 59 & 307 & 134 \\
\hline Perse & $\operatorname{tase}(\%)$ & 0 & 0 & 11,8 & 61,4 & 26,8 \\
\hline \multicolumn{7}{|c|}{ Aspek Fungsionalitas } \\
\hline 6 & $\begin{array}{l}\text { Kinerja proses lihat } \\
\text { detail gedung }\end{array}$ & 0 & 0 & 7 & 70 & 23 \\
\hline 7 & Kinerja proses navigasi & 0 & 0 & 17 & 55 & 28 \\
\hline 8 & $\begin{array}{l}\text { Kinerja proses telepon } \\
\text { gedung }\end{array}$ & 0 & 0 & 12 & 60 & 28 \\
\hline 9 & $\begin{array}{l}\text { Kinerja proses buka } \\
\text { website }\end{array}$ & 0 & 0 & 13 & 59 & 28 \\
\hline 10 & $\begin{array}{l}\text { Kemudahan yang } \\
\text { diberikan AR dalam } \\
\text { mengenali gedung } \\
\end{array}$ & 0 & 0 & 11 & 44 & 45 \\
\hline 11 & $\begin{array}{l}\text { Kemudahan yang } \\
\text { diberikan mini map } \\
\text { dalam memberikan } \\
\text { posisiuser }\end{array}$ & 0 & 0 & 10 & 60 & 30 \\
\hline 12 & $\begin{array}{l}\text { Kemudahan yang } \\
\text { diberikan map dalam } \\
\text { mencari gedung }\end{array}$ & 0 & 0 & 5 & 65 & 30 \\
\hline \multicolumn{2}{|l|}{ Total } & 0 & 0 & 75 & 413 & 212 \\
\hline Perse & $\operatorname{tase}(\%)$ & 0 & 0 & 10,7 & 59 & 30,3 \\
\hline \multicolumn{7}{|c|}{ Aspek Komunikasi Visual } \\
\hline 13 & Antarmuka aplikasi & 0 & 0 & 27 & 51 & 22 \\
\hline 14 & Peletekan informasi & 0 & 0 & 15 & 63 & 22 \\
\hline 15 & $\begin{array}{l}\text { Jenis dan ukuran huruf } \\
\text { yang digunakan mudah } \\
\text { dibaca }\end{array}$ & 0 & 0 & 6 & 58 & 36 \\
\hline 16 & $\begin{array}{l}\text { Kombinasi warna } \\
\text { aplikasi }\end{array}$ & 0 & 0 & 13 & 60 & 27 \\
\hline 17 & $\begin{array}{l}\text { Kehalusan perpindahan } \\
\text { halaman }\end{array}$ & 0 & 0 & 10 & 55 & 35 \\
\hline \multicolumn{2}{|l|}{ Total } & 0 & 0 & 71 & 287 & 142 \\
\hline \multicolumn{2}{|c|}{ Persentase $(\%)$} & 0 & 0 & 14,2 & 57,4 & 28,4 \\
\hline \multicolumn{2}{|c|}{$\begin{aligned} \text { "Tanggapan } & \rightarrow 5 \text { :Sangat baik } \\
& \rightarrow 2: \text { Kurang baik }\end{aligned}$} & $\rightarrow 1:$ & & & $\overline{\mathrm{Cuku}}$ & aaik \\
\hline
\end{tabular}

Tabel 4 berikut menunjukkan hasil dari pembagian kuesioner kepada 100 responden terhadap 17 butir pertanyaan yang dibagi menjadi 3 aspek, yaitu aspek rekayasa perangkat lunak, aspek fungsionalitas dan aspek komunikasi visual. 
Berdasarkan hasil kuesioner pada Tabel 3 dan Tabel 4, hasil kuesioner dapat disajikan menjadi beberapa bagian, yaitu:

1. Pemilih AR dan MAP

Berdasarkan hasil kuesioner pada Tabel 3didapatkan persentase tanggapan AR lebih mempermudah user dalam mengenali gedung sebesar $96 \%$ dan persentase tanggapan MAP lebih mempermudah user dalam mengenali gedung sebesar $4 \%$.

2. Aspek Rekayasa Perangkat Lunak

Tanggapan dengan persentase terbesar pada aspek rekayasa perangkat lunak adalah tanggapan baik (4) dengan nilai persentase sebesar $61,4 \%$.

3. Aspek Fungsionalitas

Tanggapan dengan persentase terbesar pada aspek fungsionalitas adalah tanggapan baik (4) dengan nilai persentase sebesar $59 \%$.

4. Aspek Komunikasi Visual

Tanggapan dengan persentase terbesar pada aspek

komunikasi visual adalah tanggapan baik (4) dengan nilai persentase sebesar $57,4 \%$.

5. Hasil Tanggapan AR

Berdasarkan dari hasil kuesioner pada nomor 10 didapatkan bahwa persentase tanggapan AR mempermudah user dalam mengenali gedung di UNTAN sebesar $89 \%$ (persentase tanggapan $4+5$ ), persentase tanggapan raguragu $11 \%$ (persentase tanggapan 3), dan persentase tanggapan AR tidak mempermudah user dalam mengenali gedung di UNTAN sebesar 0\% (persentase tanggapan $1+$ 2)

6. User Acceptance Test

Berikut adalah perhitungan untuk mengukur tingkat keberhasilan aplikasi dengan menggunakan teknik penskalaan Likert'sSummatedRating(LSR) terhadap hasil kuesioner pada Tabel 3.LSR adalah skala atau pengukuran sikap responden. LSR sangat bermanfaat untuk membandingkan skor sikap seseorang dengan distribusi skala dari sekelompok orang lainnya[11].

a. Total tanggapan pada hasil kuesioner (penjumlahan total dari 3 aspek).

i. Total tanggapan $1=0+0+0=0$

ii. Total tanggapan $2=0+0+0=0$

iii. Total tanggapan $3=59+75+71=205$

iv. Total tanggapan $4=307+413+287=1007$

v. Total tanggapan $5=134+212+142=488$

b. Total skor tanggapan pada hasil kuesioner.

i. Total skor tanggapan $1=0 \times 1=0$

ii. Total skor tanggapan $2=0 \times 2=0$

iii. Total skor tanggapan $3=205 \times 3=615$

iv. Total skor tanggapan $4=1007 \times 4=4028$

v. Total skor tanggapan $5=488 \times 5=2440$

vi. Total skor keseluruhan $=0+0+615+4028+2440=$ 7083

c. Jumlah skor untuk setiap responden.

i. Skor maksimal $=5 \times 17$ item $=85$

ii. Skor minimal $=1 \times 17$ item $=17$

iii. Skor median $\quad=3 \times 17$ item $=51$

iv. Skor kuatril I $=2 \times 17$ item $=34$

v. Skor kuartil III $=4 \times 17$ item $=68$ d. Jumlah skor untuk seluruh responden.
i. Maksimal $=85 \times 100$ responden $=8500$
ii. Minimal $=17 \times 100$ responden $=1700$
iii. Median $\quad=51 \times 100$ responden $=5100$
iv. Kuartil I $=34 \times 100$ responden $=3400$
v. Kuartil III $=68 \times 100$ responden $=6800$

e. Interpretasi jumlah skor tersebut adalah.

i. $6800<$ Skor $<8500$, artinya sangat positif (program dinilai berhasil).

ii. $5100<$ Skor $<6800$, artinya positif (program dinilai cukup berhasil).

iii. $3400<$ Skor <5100, artinya negatif (program dinilai kurang berhasil).

iv. $1700<$ Skor <3400, artinya sangat negatif (program dinilai tidak berhasil).

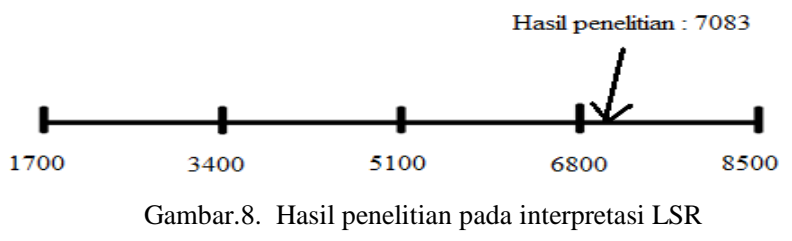

Total skor penilaian yang diperoleh dari 100 responden yakni 7083 dan berada di antara titik Kuartil III (6800) dan titik Maksimal (8500).

\section{E. Analisis Hasil}

Berdasarkan hasil pengujian yang diperoleh, analisis mengenai masing-masing hasil pengujian dapat disimpulkan sebagai berikut:

1. Berdasarkan hasil pengujian kompatibilitas, dapat diketahui bahwa aplikasi dapat berjalan dengan baik pada perangkat dengan sistem operasi Android versi 4.0 (Ice Cream Sandwich) sampai dengan 5.1 (Lollipop), dan untuk Android versi 2.3 (Gingerbread, aplikasi tidak dapat diinstall. Perangkat Android dengan versi 2.3 tidak bisa diinstall dikarenakan penggunaan GoogleMaps API v2 memerlukan libraryMapFragment, dimana library MapFragment ini memerlukan native API level $11 \mathrm{ke}$ atas [12], sedangkan versi Android 2.3 memiliki native API dengan level 10.

2. Berdasarkan hasil dari pengujian akurasi, nilai akurasi pada pengujian akurasi bernilai 100\%. Berdasarkan nilai akurasi tersebut dapat diketahui bahwa aplikasi dapat mengenali gedung dari sisi depan, kiri, kanan maupun belakang gedung dan dari jarak dekat, sedang maupun jauh.

3. Berdasarkan hasil kuesioner didapatkan, khususnya pada bagian pemilih AR dan MAP didapatkan bahwa user lebih mudahuntuk mengenali gedung di UNTAN dengan menggunakan fitur AR daripada menggunakan fitur peta digital, dimana persentase fitur AR (96\%) lebih besar dibandingkan persentase pemilih fitur MAP (4\%).

4. Berdasarkan hasil kuesioner pada 3 aspek yaitu aspek rekayasa perangkat lunak, aspek fungsionalitas dan aspek komunikasi visual didapatkan bahwa ketiga aspek tersebut mendapatkan tanggapan baik (tanggapan 4) dari responden, 
dimana tanggapan tersebut merupakan tanggapan dengan persentase terbesar dari hasil setiap aspek pada kuesioner, dengan persentase tanggapan baik pada aspek rekayasa perangkat lunak sebesar $61,4 \%$, aspek fungsionalitas sebesar 59\% dan aspek komunikasi visual sebesar 57,4\%.

5. Berdasarkan hasil kuesioner pada bagian pengelompokan tanggapan AR, dapat diketahui bahwa teknologi AR yang diimplementasikan pada aplikasi yang dibuat dapat mempermudah user untuk mengenali gedung di lingkungan UNTAN. Pilihan AR mempermudah ini memiliki persentase pemilih terbesar yaitu $89 \%$.

6. Berdasarkan hasil User Acceptance Test, dapat diketahui bahwa responden menilai bahwa aplikasi yang dibuat sangat positif dan berhasil, yang dapat dibuktikan dengan skor total dari keseluruhan data kuesioner berjumlah 7083, dimana total skor ini berada diantara kuartil III (6800) dan maksimal (8500) pada intepretasi LSR.

\section{KESIMPULAN}

Setelah dilakukan pengujian dan analisis terhadap pengimplementasian teknologi Augmented Realitypada sistem pengenalan gedung Universitas Tanjungpura, dapat disimpulkan bahwa:

1. Aplikasi yang diimplementasikan dengan teknologi Augmented Reality mempermudah user untuk mengenali gedung yang berada di lingkungan Universitas Tanjungpura dengan persentase responden yang merasa dimudahkan sebesar $89 \%$. User lebih mudah dalam mengenali gedung dengan menggunakan fitur $A R$ dibandingkan dengan fitur peta digital, dengan persentase pemilih fitur AR sebesar $96 \%$.

2. Aplikasi pengenalan gedung berbasis Android yang dibuat hanya dapat dijalankan pada perangkat Android dengan versi 4.0 (Ice Cream Sandwich) sampai dengan 5.1 (Lollipop).

3. Aspek rekayasa perangkat lunak, fungsionalitas dan komunikasi visual pada aplikasi Android dianggap baik oleh user, dimana persentase useruntuk aspek rekayasa perangkat lunak sebesar $61,4 \%$, persentase user untuk aspek fungsionalitas sebesar $59 \%$ dan persentase user untuk aspek komunikasi visual sebesar 57,4\%.

4. Aplikasi yang diimplementasikan dengan teknologi Augmented Reality dapat mengenali gedung yang berada di lingkungan Universitas Tanjungpura dari sisi depan, kiri, kanan maupun belakang gedung dan dari jarak dekat, sedang maupun jauh dengan tingkat akurasi sebesar $100 \%$.

5. Aplikasi pengenalan gedung dengan teknologi AR ini diterima user dengan sangat positif dengan skor likert sebesar 7083.

\section{DAFTAR PUSTAKA}

[1] Wibowo, T.I. 2012. UNTAN Pontianak Siap Wujudkan Kampus Modern. http://www.antarakalbar.com/berita/306334/untan-pontianaksiap-wujudkan-kampus-modern.

[2] Hendrianto, D. ,dan S, Ary Mazharuddin.2011.Augmented Reality on Android Operating System-Based Device (Case Study : Mosque Finder). Jurnal Ilmiah Kursor, Vol. 6, No. 4, Hlm 197-204.

[3] Fukuda, Shuichi. 2010 .Emotional Engineering. New York: Springer.

[4] Jacko, Julie A. ,dan Sears, Andrew.2003. Handbook of Research on Ubiquitous Computing Technology for Real Time Enterprises. United States: CRC Press.

[5] Kalkofen, D.; Sandor, C.; White, S., dan Schmalstieg, D. 2011. Visualization Techniques for Augmented Reality. Handbook of Augmented Reality. New York: Springer.

[6] Fernando, Mario. 2013. Membuat Aplikasi Android Augmented Reality Menggunakan Vuforia SDK dan Unity. Surakarta: AR Online.

[7] Seng, Ciu Bun. 2011. Android Dasar Pengoperasian Optimasi Sampai Modifikasi. DKI Jakata:Jasakom.

[8] Wetherell, J. 2011. Android-augment-reality-framework. https://github.com/ph ishman3579/android-augment-reality-framework.

[9] Sood, Raghav. 2012. Pro Android Augmented Reality. New York: Apress.

[10] Sukamto, R.A. dan Shalahuddin, M. 2013. Rekayasa Perangkat Lunak Terstruktur dan Berorientasi Objek. Bandung: Informatika Bandung.

[11] Churchill, G. A. 2005. Dasar-Dasar Riset Pemasaran, Edisi 4, Jilid I, Alih Bahasa Oleh Andriani, Dkk. Penerbit Erlangga, Jakarta.

[12] Waele, D.D. 2013. Maps V2 AndroidPart 1: Setting Up the Project. https://github.com/ddewaele/GoogleMapsV2WithActionBarSherlock/bl $\mathrm{ob} / \mathrm{master} /$ GoogleMapsV2WithActionBarSherlock/docs/part1.md. 